\title{
İşgörenlerin Örgütsel Politika Algısına Tepkilerinin Belirlenmesinde İş Tatminin Rolü*
}

Araştırma Makalesi /Research Article

\section{Esengül İPLİK ${ }^{1}$}

ÖZ: Bu çalışmanın amacı; çalışanların örgütsel politika algılarının örgütten ayrılma, ses çıkarma, sadakat ve ihmal etme davranışları üzerindeki doğrudan etkisi ile iş tatmini aracılı̆̆ıyla dolaylı etkisinin ortaya konulmasıdır. Bu amaç doğrultusunda gerçekleştirilen çalışmada kullanılan veri kolayda örnekleme yöntemiyle seçilen perakende sektörü çalışanlarından anket yoluyla toplanmıştır. Yapılan analiz sonucunda, politika algısının çalışanlarda tatminsizlik duygusuna yol açtığ ortaya konulmuştur. Ayrıca politika algısının örgütten ayrılma ve ihmal etme davranışıyla pozitif, ses çıkarma ve sadakat ile ise negatif iliş̧kili olduğu ve politika algısı ile söz konusu değişkenler arasındaki iliş̧kide iş tatminin aracılık rolünün bulunduğu belirlenmiştir.

Anahtar Kelimeler: Örgütsel Politika, Örgütten Ayrllma, Ses Çıkarma, Sadakat, İhmal Etme Jel Kodu: D23, M12

\section{Determining The Employee Reactions to Perceptions of Organizational Politics: The Role of Job Satisfaction}

\begin{abstract}
The purpose of this study is to determine the direct effect of organizational politics perceptions of employees on exit, voice, loyalty, neglect and also indirect effect through job satisfaction. The data used in the study conducted for this purpose was collected through a questionnaire from retail sector employees selected by using convenience-sampling method through surveys. As a result of the analysis, it has been revealed that the perception of politics leads to the feeling of dissatisfaction among the employees. It has been determined that the perception of politics is positively related to exit and neglect, negatively related to voice and loyalty, and that job satisfaction has a mediating role in the relationship between the perception of politics and these variables.
\end{abstract}

Keywords: Organizational Politics, Exit, Voice, Loyalty, Neglect

JEL Codes: D23, M12

Geliş Tarihi / Received: 05/02/2020

Kabul Tarihi / Accepted: 26/02/2020

\footnotetext{
* Bu makale 02-03 Kasım 2019 tarihlerinde gerçekleştirilen International Congress of Management, Economy and Policy 2019 Güz/ ICOMEP'19-Autumn'da sunulan bildirinin genişletilmiş halidir.

1 Dr. Öğr. Üyesi, Adana Alparslan Türkeş Bilim ve Teknoloji Üniversitesi İşletme Fakültesi, eiplik@atu.edu.tr, orcid.org/0000-0002-6000-1588.
} 


\section{Giriş}

Örgütler, bireylerin parasal kaynakları elde etmek için mücadele ettiği, kişisel çatışmaların yaşandığı, fayda sağlamak ve hedeflere ulaşabilmek için bireyler veya grupların bir takım etkili taktikler yürüttüğü sosyal varlıklardır. Örgüt içerisindeki bu güç ilişkilerini ve taktikleri etkileme özelliği olan politik davranış örgüt dinamikleri için vazgeçilmez bir yapı olarak görülmekte ve örgütteki politik iklimi yansıtmaktadır. Bir örgütün politik iklimini tahmin etmek karmaşık bir iştir, ancak örgütlerin daha iyi anlaşılması için çok önemlidir (Vigoda, 2000). Örgütsel işleyişin gerçek ve önemli bir boyutu olarak kabul edilen örgütsel politik iklimler, örgütün işe alım, karar alma, hedeflere ulaşma, kaynakların ve ödüllerin dağıtım süreçleri ile ilgili politika ve prosedürlerinin uygulamada nasıl gerçekleştirildiğine ilişkin çalışan algıları üzerine kuruludur (Landells ve Albrecht, 2013).

Politik iklim soyut bir kalıp değil, aynı zamanda faaliyet ve eylemlere de dönüşen bir olgudur. Çalışanlar, çalışma ortamlarının politik olduğunu düşünmeye başladıktan sonra zamanla kendileri de aktif olarak politik davranışlar sergilemeye başlamaktadır. Örgütsel politika ve çalışanların algıları arasındaki ilişki karşılıklı olarak pekiştiricidir. Yani, sürekli olarak politik davranışa maruz kaldıkları bir örgütsel ortam, çalışanın politik davranış sergilemesini zorunlu kılan bir iş ortamı oluşturmaktadır. Ayrıca, çalışanların politik davranış ile elde edilen iş çıktıları arasında bir bağın olduğunu algılaması da iş ortamında politik davranışların yoğunlaşmasına yol açan diğer bir unsurdur. Dolayısıyla, örgütsel politika algısının politik iklimi açıklamada önemli rolü bulunmaktadır (Kidron ve Vinarski Peretz, 2018: 776-777).

Çalışanların örgütün çıkarlarını gözardı ederek kendi çıkarlarını arttırmakla ilgili davranışlarını içeren örgütsel politika olumsuz ya da yıkıcı iş sonuçlarına yol açan işyeri faaliyetleri olarak görülmektedir. Bu nedenle örgütsel politikanın önemi, çalışan tutum ve davranışları üzerindeki potansiyel sonuçları ve iş çıktıları üzerindeki etkisinde yatmaktadır. Yapılan çalışmalar politikanın karar verme, terfi ve ödüller gibi normal örgütsel süreçleri etkilediği, politika algısının bireysel ve örgütsel düzeyde verimlilik ve performansa zarar verdiğini ortaya koymaktadır. Dolayısıyla çalışanların politika algılarını anlamak örgütleri anlamak açısından büyük öneme sahiptir. Bu bağlamda bu çalışmanın amacı, çalışanlarda adaletsizlik ve eşitsizlik duygusu yaratarak çalışanın örgüte yönelik tutum ve davranışlarını olumsuz etkileyebilen bir unsur olan örgütsel politika algısının iş tatminine etkisi ve çalışanların buna verdiği tepkilerin (örgütten ayrılma, ses çıkarma, sadakat ve ihmal etme) belirlenmesidir.

\section{Kavramsal Çerçeve}

\section{1. Örgütsel Politika}

Genel olarak çalışanların kendi kişisel çıkarlarını maksimize etmek için stratejik olarak tasarladıkları davranış olarak tanımlanan (Ferris, Russ ve Fandt, 1989: 145) örgütsel politika, örgütün genel hedeflerine veya diğer kişilerin çıkarlarına aykırı bir 
olgu olarak görülmektedir (Vigoda, 2000). Örgütsel politikanın en temel özelliği, örgüt üyelerinin, başkalarını etkileme ve çıkarlarını güvence altına alma çabalarında güç kullanmaya veya alternatif olarak örgüt içinde kendileri açısından olumsuz sonuçlar doğuracak faaliyetlerden kaçınmaya hazır olmalarıdır (Vigoda, 2001).

Literatürde örgütsel politika kavramı ile ilgili birbirinden farklı pek çok tanım bulunmakta ve bu tanımlar incelendiğinde aralarında ortak birkaç noktanın varlığ 1 göze çarpmaktadır. Bu noktalardan bir tanesi politik faaliyetlerin, sosyal etkiyi kullanmanın bir yolu olarak ele alınmasıdır. Sosyal etki teorisine göre, kişilerarası ilişkilerin çoğu bir tür sosyal etki içerir; yani insanlar başkalarını etkilemek isterken, aynı zamanda kendileri de başkaları tarafından etkilenmektedirler. Sosyal etki, bireyler tarafından olumlu sonuçları arttırmak ve kişiler arası etkileşimle ilgili olası olumsuz sonuçları azaltmak için kullanılan taktikleri içermektedir (Ferris, vd., 2017: 6). Örgütsel politika tanımlarında yer alan diğer bir nokta da çalışanların genellikle kendi çıkarlarını geliştirmek veya korumak ve kendileri için değerli bir sonucu etkilemek amacıyla politik davranışlar sergilediğidir. Son olarak, politik davranış için en az iki tarafın varlığı ve bu iki tarafın birbirinden farklı çıkarlara sahip olması gerektiği birçok tanımda açık ya da örtülü bir şekilde yer almaktadır. Bu bakış açılarının tek bir genel tanımla birleştirilmesi sonucu örgütsel politika, bireyin kendi çıkarlarını desteklemeye veya korumaya yardımcı olacak ödülleri sağlayabilenlere yönelik gerçekleştirdiği sosyal etki taktikleri olarak tanımlanabilmektedir (Cropanzano, Kacmar ve Bozeman, 1995: 7; Kacmar ve Carlson, 1997: 629).

Örgüt içinde istenilen kişisel sonuçlara ulaşmak üzere güç ve diğer kaynakları elde etmek, geliştirmek ve kullanmak için yapılan eylemleri kapsayan örgütsel politika, araçlar ve amaçlar olmak üzere iki farklı yolla tanımlanmaktadır. Araç yaklaşımı altında, örgütsel politika, çalışanlar tarafından gerçekleştirilen ve işveren tarafından onaylanan ya da onaylanmayan kendine güven, rasyonellik, faydaların değişimi, engelleme, işbirliği ve kendini zorla kabul ettirme gibi davranışları kapsamaktadır. Örgütsel politikanın amaç yaklaşımı ise, kişinin kendine hizmet eden ve örgütün çıkarlarına ters düşen davranışları kapsamaktadır. Belirsizlik ve etkililik derecesi, örgütsel politika algısını doğuran koşullar olarak sınıflandırılmaktadır. Belirsiz amaç ve prosedürler ile rol ve sorumluluklardaki belirsizlik bireylerin politik davranış göstermeleri için firsatlar yaratmaktadır. Politik davranışın kişisel hedeflere ulaşmada ne kadar etkili olduğu, politik davranış1 teşvik eden diğer bir unsurdur (Iqbal, 2016: 612).

Örgüt içerisinde politik davranışların, çalışanların üstlendikleri görevleri yeterince benimsemediği; işiyle yeterince duygusal bağ kuramadığı; iş ortamında sosyal etkileşimler ve davranış biçimlerine ilişkin kesinleşmiş, katı kural ve standartların olmadığı dolayısıyla belirsizliğin yüksek olduğu; fırsatlar veya tehditlerin politik davranışın yararlı olduğuna ilişkin algı yarattığ1; elde edilebilecek potansiyel sonuçların birey için önemli olduğu ve örgüt içerisinde politik davranışlarda bulunan diğer kişileri özellikle de başarılı bir şekilde yapanları gördüğü 
durumlarda ortaya çıkması muhtemeldir (Ferris vd. 1989: 147). Bireyin cinsiyeti ve Makyavelizm (başarılı olmak için her şeyi yapmak) gibi belirli kişisel özelliklerine sahip olması da, politik davranışlarda bulunma potansiyelini artırabilmektedir (Kacmar ve Ferris, 1993: 70).

Örgütsel politika, Kacmar ve Ferris (1991) tarafından üç faktörlü bir yapı olarak kavramsallaştırılmıştır. Genel politik davranış olarak adlandırılan ilk boyut, bireyin kendisi için değerli olan sonuçları elde etmek için sergiledikleri kendi çıkarlarına hizmet eden davranışları kapsamaktadır. Bu tür politik davranışlar özellikle yönetmelik ve düzenlemelerin yeterli olmadığ 1 , belirsizlik altında karar vermek zorunda kalındığın ve değerli kaynaklar kıt olduğu durumlarda daha fazla görülebilmektedir. Çalışanlara yol gösterecek belirli kural ve düzenlemelerin bulunmaması durumunda, bireyler kabul edilebilir davranışlarla ilgili çok az bilgiye sahip olmakta ve bu nedenle de kendi kurallarını geliştirmektedirler. Dolayısıyla bireyler, kendilerine bırakıldığında, genellikle kendi çıkarlarına hizmet eden ve konumlarını daha iyi hale getiren kurallar geliştirmektedirler (Kacmar ve Carlson, 1997: 629). Bireyin almas1 gereken karar, eksik veya belirsiz bilgiye dayandığında ve karar vericinin mevcut verilerin analizini ve yorumunu kendisi yapması gerekmektedir. Belirsiz veya eksik bilgiler, etkin olmayan kararlarla sonuçlanan farklı şekillerde kullanılabilmekte, bu durumda da alınan kararların politik olduğu söylenebilmektedir (Drory ve Romm, 1990; Gull ve Zaidi, 2012)

Örgütsel politikanın ikinci boyutu olan hedefe ulaşmak için iyi geçinme, bireyin elde ettiği değerli sonuçları korumak için herkesle iyi geçinme ve çatışmadan kaçınma davranışlarını içermektedir. Bazı kişiler elde ettikleri değerleri korumak için çatışmadan kaçınmak isteyebilmekte ve bu nedenle başkalarının davranışlarına direnmezler. Bu politik olmayan bir eylem gibi görünse de, aslında bir tür politik davranış olarak kabul edilebilir. Örgütlerdeki politik ve politik olmayan davranışlar arasındaki ayrımın niyet temelinde yapılabileceği öne sürülmektedir. Diğer bir deyişle, bir davranış bireyin kendi çıkarlarını geliştirmek için özel olarak çıkarılmışsa, birey politik davranıyor demektir. Herhangi bir şey yapmamak veya iyi geçinmek, politik bir ortamda çalışırken kişinin kendi çıkarlarını koruması için makul ve karlı bir yaklaşım olabilmektedir (Kacmar ve Carlson, 1997: 630).

Örgütsel politikanın son boyutu olan terfi ve ücret politikaları örgütlerin, politik uygulamalarla politik davranışı nasıl ödüllendirdiği ve kalıcı hale getirebildiği ile ilgilidir. Örgütsel karar vericiler bunu bilinçli olarak yapmasalar da, geliştirilen ve uygulanan insan kaynakları sistemleri, politik davranış sergileyenleri ödüllendirirken, politik davranış sergilemeyenleri cezalandırabilmektedir. $\mathrm{Bu}$ tür uygulamalar, insan kaynakları kararlarının hemen hemen her alanında politik faaliyetlerin yaygın olacağı bir kültüre yol açabilmektedir. Örneğin, birey odaklı ödüllendirmeler örgüt içerisinde bireysel davranışların artmasına neden olacaktır. Bireysel davranış da, örgüt odaklı davranışların aksine, çoğunlukla bireyin kendi 
çıkarına olan ve doğası gereği politik davranışlardır. $\mathrm{Bu}$ tür bir davranış ödüllendirildiğinde veya güçlendirildiğinde, ödülü korumak için kullanılan taktikler muhtemelen tekrarlanacaktır. Dolayısıyla örgütler farkında olmadan politik davranışı teşvik eden ve ödüllendiren bir ortam yaratmış olacaklardır (Kacmar ve Ferris, 1993: 71).

\section{2. İş Tatmini}

Çalışan performansı ve motivasyonunun belirleyicilerinden olan ve örgütün verimliliği üzerinde önemli bir etkisi bulunan iş tatmini, örgütsel davranışın sıkça araştırılan ve en önemli konularından birisi olarak kabul edilmektedir. Bir kişinin işinden beklentisi ile elde ettiği arasındaki ilişkinin bir fonksiyonu olarak ele alınan iş tatmini, farklı araştırmacılar tarafından farklı bakış açılarıyla ele alınmış ve tanımlanmıştır (Aziri, 2011: 77). Buna göre, iş tatmini Locke (1969: 319) tarafından bireyin işini, elde etmek istediği değerlere ulaşmasını sağlayan bir iş olarak algılaması sonucu ortaya çıkan olumlu duygusal durum olarak tanımlanmaktadır. Kalleberg (1977: 126), iş tatminini bir çalışanın örgütte işgal ettiği iş rollerine karşı duygusal tepkisi şeklinde tanımlarken; Aziri (2011: 78) ise, işin bireyin maddi ve psikolojik ihtiyaçlarını ne düzeyde karşıladığına dair algısı sonucu ortaya çıkan duygular şeklinde tanımlamaktadır.

Genel olarak, işle ilgili faktörler, kişilik özellikleri ve iş dışındaki diğer sosyal ve grup ilişkileri gibi üç alanda sahip olunan birçok özel tutumun sonucu olarak ortaya çıkan genel bir tutum şeklinde tanımlanan iş tatmini olgusunu açıklamak ve anlamak için birçok farklı teori geliştirilmiştir. Buna göre iş tatmini üzerine kurulan teorilerden ilki durumsal teoriler olarak adlandırılmaktadır. Bu teoriye göre, iş tatmini bireyin yaptığı işin niteliğinden veya çevrenin diğer özelliklerinden kaynaklanmaktadır. Yatkınlık yaklaşımı olarak adlandırılan diğer teori, iş tatmininin bireyin kişilik özelliklerine bağlı olarak ortaya çıktığ varsayımına dayanırken; etkileşimci teoriler, iş tatmininin durumsal ve kişisel faktörlerinin etkileşiminden kaynaklandığını öngörmektedir. Bu teoriler içerisinde araştırmacıların en çok ilgisini çeken ve desteklenen teoriler İş Özellikleri Teorisi, Değer-Algı Teorisi ve Cornell Modeli'dir (Judge ve Klinger, 2008).

İş tatminini en iyi açıklayan faktörün işin özellikleri olduğunu ileri süren iş özellikleri teorisine göre; çalışanların işe yönelik tutum ve davranışları, beceri çeşitliliği, görev bütünlüğü, görevin önemi, özerklik ve geribildirim olmak üzere beş temel iş özelliğinden etkilenmektedir. Bu beş temel iş özelliği bireyin yaptığ1 işi anlamlı olarak algılaması, işin sonuçları hakkında sorumluluk duyması ve işin sonuçları hakkında bilgi edinmesi gibi üç kritik psikolojik durumun ortaya çıkmasına neden olmaktadır. Buna göre, beceri çeşitliliğgi, görev bütünlüğü ve görevin önemi yapılan işin anlamlılığını arttırırken; özerklik, işin sonuçlarına ilişkin sorumluluk duymayı, geribildirim ise işin sonuçları hakkında bilgi sahibi olmayı sağlamaktadır. Bu üç psikolojik durum da işe devamsızlığı ve personel devir hızını düşürürken, içsel iş motivasyon, iş performansı ve iş tatmin düzeylerinin artmasına yol açmaktadır (Hackman ve Oldham, 1974: 2-4). 
Değer-Alg1 Teorisine göre, değerler, bireyi işinde neyin tatmin ettiğinin önemli bir belirleyicisidir. Dolayısıyla, çalışanlar, kendileri için önemli olan iş değerlerini elde ettiği ölçüde işlerinden tatmin olmaktadırlar. İş tatminini açıklamaya çalışan önemli teorilerden bir diğeri de Cornell Modeli'dir. Bu modele göre iş tatmini çalışanların işteki rolüne katkıları (eğitim, deneyim, zaman ve çaba gibi) olarak tanımlanan rol girdileri ile işten elde ettikleri (ücret, statü, çalışma koşulları ve içsel faktörler gibi) olarak tanımlanan rol çıktıları arasındaki dengenin bir fonksiyonudur. Dolayısıyla, çalışanın işi için yaptıklarına karşılık elde ettiği çıtılar ne kadar fazla olursa üstlendiği rolden duyduğu tatmin de o kadar yüksek olmaktadır (Judge vd., 2001: 31).

Yapılan çalışmalar, çalışanların işi ve çevresi hakkındaki beklentileri ile ilgili olan iş tatmininin, performans (Iaffaldano ve Muchinsky, 1985; Judge vd., 2001), örgütsel bağl1lik (Markovits vd., 2010; Williams ve Hazer, 1986), örgütsel vatandaşlık davranışı (Arif ve Chohan, 2012; Bateman ve Organ, 1983; Schappe, 1998), işe devamsızlık (Bridges, 1980; Matrunola, 1996; Scott ve Taylor, 1985), personel devir hızı ve işten ayrılma niyeti (Netemeyer, Burton ve Johnston, 1995; Scott vd., 2006) gibi birçok çalışan tutum ve davranışını etkileyebileceğini ortaya koymaktadır. Dolayısıyla, çalışanların iş tatminine nasıl tepki verdiklerini anlamanın örgütsel etkinlik açısından önemli etkilere sahip olduğu söylenebilmektedir.

\section{3. Örgütten Ayrılma, Ses Çıkarma, Sadakat ve İhmal Etme}

Çalışanlar sürekli olarak örgütte yöneticileriyle fikir ayrılığına düşmek, kendilerine verilen iş veya görevler konusunda hayal kırıklıkları yaşamak ve iş arkadaşlarının davranışlarından rahatsızlık duymak gibi işle ilgili bir takım farklı sorunlarla karşı karşıya kalmakta ve bu sorunlarla farklı şekillerde başa çıkmaya çalışmaktadırlar. Çalışanların olumsuz duygular yaratan bu sorunlu olaylarla başa çıkma şekli, örgütle ilişkileri ve örgütün etkinliği üzerinde önemli bir etkiye sahip olabilmektedir (Hagedoorn vd., 1999). Buna göre, çalışma koşullarını iyileştirme, sorunun çözümü ile ilgili önerilerde bulunma ve sorun hakkında yöneticileri uyarma gibi yapıcı tepkiler örgütsel verimlilik ve etkinliği artırmaya yardımcı olabilirken; istifa, işe devamsızlık veya psikolojik geri çekilme gibi daha az yapıcı tepkiler kurumun karlılığını ve hayatta kalma becerisini olumsuz yönde etkileyebilmektedir (Leck ve Saunders, 1992).

Hirschman (1970) tarafından yapılan çalışmada çalışanların örgüt içerisinde yaşadığı olumsuzluklara örgütten ayrılma (exit), ses çıkarma (voice) veya sadakat (loyalty) şeklinde üç temel davranıştan biriyle yanıt verdiği ileri sürülmüş, daha sonra Rusbult, Zembrodt ve Gunn (1982) tarafindan yapılan çalışmayla ihmal etme davranışı modele eklenerek dörtlü bir yapı ortaya konulmuştur. Örgüt içerisinde ortaya çıkan sorunlara verilen bu dört tepki daha sonraki çalışmalarda (Farrell, 1983; Hagedoorn vd., 1999; Rusbult ve Zembrodt, 1983) genişletilerek yapıcı/yıkıcı boyut ile pasif/aktif boyut içerisine yerleştirilmiştir (Şekil 1). 
Ses çıkarma ve sadakat, genellikle çalışanın örgütle olan ilişkisini sürdürmesini veya canlandırmasını amaçlayan yapıcı tepkiler olarak sınıflandırılırken, örgütten ayrılma ve ihmal, nispeten yıkıcı davranışlar olarak sınıflandırılmaktadır. İkinci boyut olan aktif/pasif sınıflandırması açısından değerlendirildiğinde ise örgütten ayrılma ve ses çıkarma aktif davranışlar (yani, birey örgütle olan ilişki hakkında bir şeyler yapıyor), sadakat ve ihmal ise daha pasif tepkiler olarak sinıflandirılmaktadır (Rusbult vd., 1982).

Şekil 1: Çalışanların Sorunlu Olaylara Gösterdiği Tepkiler

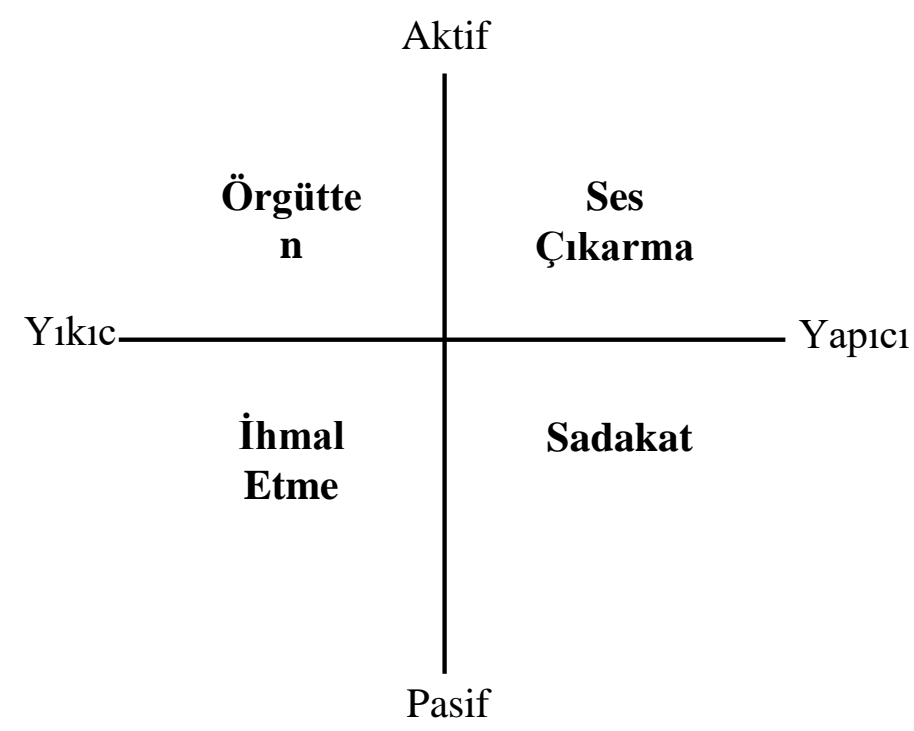

Kaynak: Hagedoorn vd., 1999: 312

Örgütte yaşanan sorunlara çalışanın verdiği tepkilerden biri olan örgütten ayrılma, çalışanın işten gönüllü olarak ayrılmayı, istifa etmeyi düşünmesi ve başka bir iş aramasını ifade etmektedir. Çalışan için zor bir karar olan örgütten ayrılma, genellikle çalışanın durumun iyileşeceğine dair inancının kalmaması durumunda söz konusu olmaktadır. Aktif ve yapıcı bir davranış olarak değerlendirilen ses çıkarma, yöneticiyle tartışarak, çözümler önererek, dışarıdan yardım alarak durumu değiştirmeye çalışmak olarak tanımlanmaktadır. Sorunun çözümü için çabalamak yerine durumu değiştirme girişimini ifade eden ses çıkarmanın örgüt açısından, sorunların tespiti ve düzeltilmesi, iş sürecindeki beklenmeyen hataların başarılı bir şekilde yönetimi ve önlenmesi ile karar alma kalitesinin iyileştirilmesi gibi faydaları bulunmaktadır. Örgütte kötüleşen koşullarla karşı karşıya kaldığında, bazı çalışanlar örgütten ayrılmak ya da ses çıkarmak yerine, soruna herhangi bir tepki vermeden çalışmaya devam etmektedirler. Buna göre, ses çıkarma gibi yapıcı ama daha pasif bir davranış olarak sınıflandırılan sadakat, koşulların iyileştirilmesi için sabırla beklemek, örgütün doğru şeyi yapacağına güvenmek anlamına gelmektedir. Sadakat, ses çıkarma ile örgütten ayrılma arasında bağımsız bir hareket tarzı olabileceği gibi, sorun devam ettikçe diğer 
davranışlara yol açan geçici bir davranış tarzı da olabilmektedir. Son olarak pasif ve yıkıcı bir davranış olarak sınıflandırılan ihmal etme ise, sürekli işe gecikme veya devamsızlık gibi davranışlar sergileme ve işteki zamanı kişisel işler için kullanma şeklinde tanımlanmaktadır (Farrell, 1983: 598; Rusbult vd., 1988: 601; Shin, 2013: 8).

\subsection{Kavramlar Arasındaki İlişkiler ve Araştırma Hipotezleri}

Örgütsel politika, birçok araştırmacı tarafından kişisel çıkarlar için kullanılan ve onaylanmayan davranışları içeren olumsuz bir olgu olarak değerlendirilmesine rağmen, bazı araştırmacılar tarafından örgütlerin temel işleyişine katkıda bulunabilecek sosyal bir işlev olarak da değerlendirilmektedir. Buna göre, politika, çalışanların müşterilerle başa çıkmak için doğru şekilde davranmasını ve işlerine yaklaşımlarında daha profesyonel olmalarını sağladığ 1 için örgüte yarar sağlayabilmektedir. Politik olarak yetenekli olma, bireyin ve örgütün başarısını artırabilmekte ve örgütsel değişimi ve çevreye adaptasyonu kolaylaştırabilmektedir. Dolayısıyla politik davranış, örgütün vizyon ve hedeflerine hizmet ettiğinde, takım çalışmasını geliştirdiğinde, güveni arttırdığında ve etik olarak iyi dengelendiğinde olumlu olarak değerlendirilebilmektedir (Cacciattolo, 2015; Curtis, 2003).

Çoğunlukla kişisel çıkarların güvence altına alınmasını veya organizasyon içindeki olumsuz sonuçlardan kaçınmayı amaçlayan davranışları içeren örgütsel politika, genel olarak insan davranışının karanlık tarafının temsilcisi olarak değerlendirildiği için araştırmalarda çoğunlukla politikanın hem çalışanlar hem de çalışma ortamı üzerindeki olumsuz etkilerine odaklanılmaktadır. Örgütsel politika manipülasyon, zorlayıcı etki taktikleri ile diğer yıkıcı ve yarı-yasal eylemlerle neredeyse eş anlamlı olarak kabul edilmekte ve bu betimleme, örgütsel politikanın örgütün ortak yararına aykırı olduğu, her düzeyde (birey, takım, örgüt) performansa zarar verebileceği ve çalışan tutum ve davranışlarını olumsuz etkileyebileceği varsayımına yol açmaktadır (Vigoda-Gadot ve Talmud, 2010). Politikanın çalışan tutumları üzerindeki olumsuz etkisi, işveren ile çalışan arasındaki sosyal sözleşme üzerindeki etkisinden kaynaklanmaktadır (Cropanzano vd., 1997). Buna göre çalışanların promosyonlar, ödüller ve ücret artışlarının liyakate göre düzenlendiğine dair inançları örgüte ve işlerine yönelik olumlu tutum ve davranışlar sergilemelerine yol açarken, promosyonlar, ödüller ve ücret artışlarının liyakat yerine politik düşüncelere dayandığını algılamaları örgüte olan bağlılıklarının ve iş tatminin azalmasına neden olmaktadır (Witt, Andrews ve Kacmar, 2000, s. 343). Araştırmacılar (Aybar ve Marşap, 2018; Ferris vd. 1989; Ferris ve Kacmar, 1992; Goo, Choi ve Choi, 2019; Huang, Chuang ve Lin, 2003; Öztürk ve Ay, 2018) yüksek iş stresi, tükenmişlik, devamsızlık ve devir hızı ile düşük tatmin, bağl1lık ve performans gibi birçok olumsuz örgütsel sonucun büyük ölçüde politik örgüt ortamlarının bir yansıması olduğunu öne sürmektedirler. 
$\mathrm{H}_{1}$ : Örgütsel politika algısı ile iş tatmini arasında negatif yönlü bir ilişki vardır.

Sürekli sorunlu çalışma ortamı veya olumsuz örgüt koşulları ile karşı karşıya kalan çalışanlar gittikçe daha fazla hayal kırıklığına uğramakta ve hayal kırıklığı artan çalışanlar da hissettikleri olumsuz örgütsel koşullara çeşitli şekillerde yanıt verebilmektedirler. Bazıları durumu değiştirmek için seslerini yükseltmeyi veya sabırla ve örgüte duyduğu güvenle durumun düzeleceğine inanmayı seçerken, bazıları ise sessiz kalmayı veya örgütten tamamen ayrılmayı dahi düşünebilmektedirler (Hagedoorn vd., 1999; Hsiung ve Yang, 2012). Bu bağlamda, çalışanlar, çalışma ortamında önemli bir stresör olarak kabul edilen (Iqbal, 2016, s. 613) politik davranışlardan zarar gördüklerini algıladıklarında da bu dört tepkiden birini (örgütten ayrılma, ses çıkarma, ihmal etme ve sadakat) gösterebilmektedirler (Başar ve Varoğlu, 2016; Iqbal, 2016; Vigoda, 2000, 2001).

$\mathrm{H}_{2}$ : Örgütsel politika algısı ile örgütten ayrılma arasında pozitif yönlü bir ilişki vardir.

$\mathrm{H}_{3}$ : Örgütsel politika algısı ile ses çıkarma arasında negatif yönlü bir ilişki vardır.

$\mathrm{H}_{4}$ : Örgütsel politika algısı ile sadakat arasında negatif yönlü bir ilişki vardır.

$\mathrm{H}_{5}$ : Örgütsel politika algısı ile ihmal etme arasında pozitif yönlü bir ilişki vardır.

Çalışanların hangi koşullar altında örgütten ayrılma, ses çıkarma, ihmal ve sadakat ile tepki verdikleri sorusunu ele alan önceki çalışmalarda çoğunlukla adaletsizlik algısı, örgütsel bağlılık ve iş tatmini gibi farklı yordayıcı değişkenler ön plana çıkmaktadır. Bunlar içerisinde en sık incelenen yordayıcı değişkenlerden biri olan iş tatmini, yapıcı tepkilerin (ses çıkarma ve sadakat) uyarıcısı ve yıkıcı tepkilerin (örgütten ayrılma ve ihmal etme) ise bastırıcısı olarak görülmektedir. Yapılan önceki çalışmalar (Farrell, 1983; Rusbult vd., 1988) da genel olarak işlerinden tatmin olan çalışanların, çalışma koşullarını daha da iyileştirmek için güçlü bir şekilde motive olduklarını, çalışma koşullarının iyileşme ihtimali konusunda daha iyimser düşündüklerini, buna karşılık örgütten ayrılma ve işlerini ihmal etme düzeylerinin ise tatminsiz çalışanlara kıyasla daha düşük olduğunu ortaya koymaktadır.

$\mathrm{H}_{6}$ : İş tatmini ile örgütten ayrılma arasında negatif yönlü bir ilişki vardır.

$\mathrm{H}_{7}$ : İş tatmini ile ses çıkarma arasında pozitif yönlü bir ilişki vardır.

$\mathrm{H}_{8}$ : İş tatmini ile sadakat arasında pozitif yönlü bir ilişki vardır.

$\mathrm{H}_{9}$ : İş tatmini ile ihmal etme arasında negatif yönlü bir ilişki vardır.

Çalışanların örgütsel politika algıları ile örgütten ayrılma, ses çıkarma, sadakat ve ihmal etme davranışlarının birlikte ele alındığı önceki çalışmalar söz konusu değişkenler arasında anlamlı ilişkiler olduğunu ortaya koymaktadır. Aynı şekilde iş tatmininin örgütten ayrılma, ses çıkarma, sadakat ve ihmal etme davranışlarının önemli bir yordayıcısı olduğunun yapılan çalışmalarla ortaya konulduğu görülmektedir. Dolayısıyla, söz konusu değişkenler arasında doğrudan ilişkilerin 
olması, çalışanların örgütsel politika algıları ile örgütten ayrılma, ses çıkarma, sadakat ve ihmal etme davranışları arasındaki ilişkide iş tatminin aracılık rolü olabileceğine işaret etmektedir.

$\mathrm{H}_{10}$ : Örgütsel politika algısının örgütten ayrılmaya etkisinde iş tatminin aracılık rolü vardır.

$\mathrm{H}_{11}$ : Örgütsel politika algısının ihmal davranışına etkisinde iş tatminin aracılık rolü vardır

$\mathrm{H}_{12}$ : Örgütsel politika algısının sadakat etkisinde iş tatminin aracılık rolü vardır.

$\mathrm{H}_{13}$ : Örgütsel politika algısının ses çıkarma davranışına etkisinde iş tatminin aracılık rolü vardır.

Örgütsel politika algısı, iş tatmini, örgütten ayrılma, ses çıkarma, sadakat ve ihmal etme davranışlarına ilişkin yapılan çalışmaların incelenmesi sonucu geliştirilen hipotezlere bağlı olarak Şekil 2'de yer alan araştırma modeli oluşturulmuştur.

Şekil 2: Araştırma Modeli

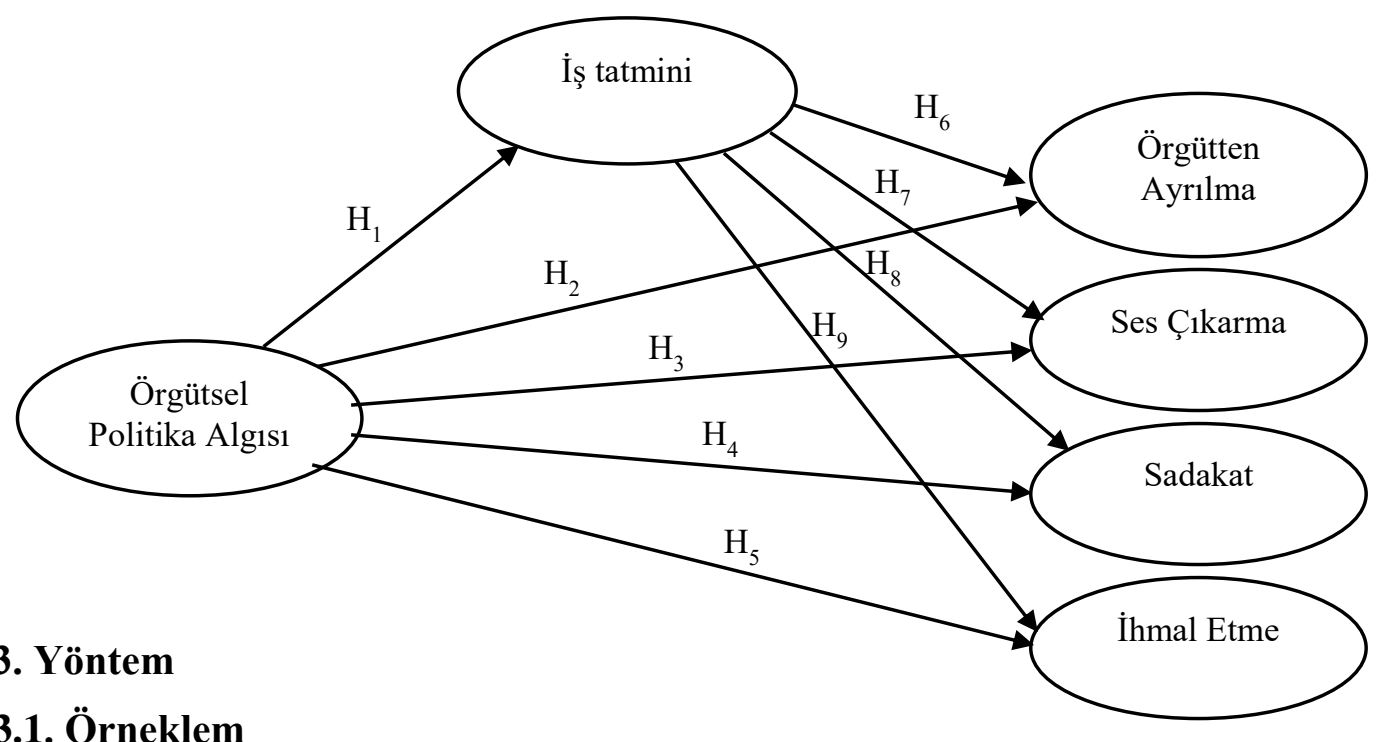

\section{1. Örneklem}

Çalışanların örgütsel politika algılarının örgütten ayrılma, ses çıkarma, sadakat ve ihmal etme davranışları üzerindeki doğrudan etkisi ile iş tatmini aracılığıyla dolaylı etkisinin ortaya konulmasının amaçlandığı bu çalışmada kullanılan veri Adana İlinde perakende sektöründe faaliyet gösteren firmaların çalışanlarından kolayda örnekleme yöntemi kullanılarak toplanmıştır. Hazırlanan anket toplam 350 çalışana ulaştırılmıştır. Ancak bu anketlerden 320 adedi geri dönmüş ve geri dönen anketlerin de 2'si hatalı doldurulması sebebiyle çalışma dışında bırakılmıştır. Dolayısıyla analizde kullanılan toplam anket sayısı 318 olmuştur. Örnekleme ilişkin demografik verilere göre, anketi cevaplayan çalışanların \%57,7'si erkek, \%42,3'ü kadın; \%35,8'i evli, \%64,2'si ise bekârdır. Yaş ortalaması 28,8 olan katılımcıların, perakende sektöründeki ortalama çalışma 
süresi ise 6,16 olarak tespit edilmiştir. Örneklemin eğitim durumu incelendiğinde \%39,6'sının lise, \%32,1'inin önlisans, \%22'sinin üniversite, 2,5'inin ilkokul ve $\% 3,8$ 'inin ise yükseklisans mezunu olduğu belirlenirken, aylık gelirinin ise, $\% 70,1$ 'inin 1500-3000 aras1, \%14,5'inin 3001-4500 ve \%12,3'ünün ise 1500 TL'nin altında olduğu belirlenmiştir.

\section{3. Ölçüm Araçları}

Çalışmada veri toplamak amacıyla kullanılan anket formu, yapılan ayrıntılı literatür incelemesi sonucu daha önce yapılan çalışmalarla geçerlik ve güvenirlikleri ispatlanmış ölçekler belirlenerek hazırlanmıştır.

Örgütsel Politika Ölçeği. Çalışanların örgütsel politika algısının ölçülmesi için Kacmar ve Carlson (1997) tarafından geliştirilen genel politik davranış, hedefe ulaşmak için iyi geçinmek ve terfi politikaları şeklinde 3 boyut ve 15 ifadeden oluşan ölçek kullanılmıştır. Ölçekte genel politik davranış 2 ifadeyle, hedefe ulaşmak için iyi geçinme 7 ifadeyle ve terfi politikaları ise 6 ifadeyle ölçülmüştür. Söz konusu ölçeğe ilişkin daha önce yapılan çalışmalarda Cronbach Alfa değerleri Vigoda (2000) tarafından yapılan çalışmada 0,77 olarak tespit edilirken, Ferris ve Kacmar (1992) tarafından yapılan çalışmada ise 0,74 olarak belirlenmiştir.

İş Tatmini Ölçeği. Çalışanların iş tatmin düzeylerini ölçmek amacıyla Cammann vd. (1983) tarafindan geliştirilmiş olan tek boyut ve 3 ifadeden oluşan ölçek kullanılmıştır. İş tatmininin ölçülmesinde yaygın olarak kullanılan ölçeğin iç tutarlığının yapılan önceki çalışmalarda (Igelans ve Roussel, 1999; McLain, 1995; Siegall ve McDonald, 1995) 0,83 ila 0,94 arasında değişen oldukça yüksek değerlerde olduğu tespit edilmiştir.

Örgütten Ayrılma - Ses Çıkarma - Sadakat - Íhmal Etme. Örgüt içerisinde algılanan olumsuzluklara verilen olası tepkileri içeren modelde yer alan örgütten ayrılma, ses çıkarma, sadakat ve ihmal etme davranışlarının ölçümünde Rusbult vd. (1988) tarafından geliştirilen ve toplam 18 ifadeden oluşan ölçek kullanılmıştır. Ölçekte örgütten ayrılma ve ihmal etme davranışları dörder ifadeyle, sadakat ve ses çıkarma davranışları ise beşer ifadeyle ölçülmüştür. Ölçeğin boyutlarına ilişkin güvenirlik değerleri Rusbult vd. (1988) tarafından yapılan çalışmada örgütten ayrılma değişkeni için $\alpha=0,97$, ses çıkarma için $\alpha=$ 0,77 , sadakat için $\alpha=0,70$ ve ihmal etme davranışı için ise $\alpha=0,82$ olarak ölçülmüştür.

\section{Bulgular}

\subsection{Faktör Analizi Sonuçları}

Yapılan çalışmada kapsamında öncelikle keşfedici ve doğrulayıcı faktör analizleri yapılarak kullanılan ölçeklerin yapısal geçerliği ortaya konulmuştur. Bu doğrultuda ilk olarak ölçeklerin faktör yapılarını incelemek amacıyla keşfedici faktör analizi yapılmıştır. Yapılan analiz sonucunda veri setinin faktör analizi için uygun olup olmadı̆̆ını ortaya koyan Kaiser-Meyer-Olkin (KMO) örneklem 
uygunluğu testi değeri 0,93 olarak belirlenmiştir. Elde edilen bu sonuç çok iyi düzeyde örneklem uygunluğunu ifade etmektedir (Gürbüz ve Şahin, 2017: 317). Ayrıca, yapılan Bartlett'in küresellik testi sonuçlarının anlamlı $\left(\chi^{2}=8207,302\right.$, $\mathrm{p}<0,01)$ olduğu da tespit edilmiştir. Dolayısıyla mevcut veri setinin çoklu normal dağılımlı ana kütle ve faktör analizi için uygun olduğu söylenebilmektedir. Temel bileşenler yöntemi ve varimax döndürme yöntemi kullanılarak gerçekleştirilen faktör analizi sonucunda 8 faktörlü bir yapı ortaya çıkmıştır. Faktörlerin varyansı açıklama oranı ise \% 73,55 olarak tespit edilmiştir. Ölçeklerde yer alan ifadelerin faktör yükleri 0,67 ile 0,84 arasında değişen değerler almıştır.

Yapılan keşfedici faktör analizi sonuçları doğrultusunda ortaya çıkan 8 faktörlü yapının elde edilen verilerle uyumlu olup olmadığını incelemek amaciyla doğrulayıcı faktör analizi (DFA) kullanılmıștır. Keşfedici faktör analizinde örgütsel politika algısının 3 boyutlu yapısı ortaya konulduğu için bu değişken modelde 2. düzey DFA ile değerlendirilmiştir. DFA en yüksek olabilirlik (Maksimum Likelihood) kestirim yöntemi kullanılarak gerçekleştirilmiştir. Analiz sonucu elde edilen uyum iyiliği değerleri $(\chi / \mathrm{sd}=1,55 ; p<, 01 ; \mathrm{CFI}=, 87$; TLI = ,96; RMSEA = ,04), ölçüm modelinin iyi düzeyde uyum sağladığını ortaya koymaktadır (Gürbüz ve Şahin, 2017: 343).

Çalışmada kullanılan ölçeklerin güvenirliklerini test etmek amacıyla Cronbach Alfa değerlerine bakılmıştır. Ölçme aracına göre değişmekle birlikte önerilen en düşük Cronbach Alfa katsayısı 0,70 olarak belirlenmektedir (Panayides, 2013: 689). Yapılan analiz sonucunda ölçeklere ilişkin elde edilen Cronbach Alfa katsayıları Tablo 1'de görülmektedir. Buna göre örgütsel politika algısı ölçeğinin Cronbach Alfa değeri 0,82, iş tatmininin 0,91, örgütten ayrılmanın 0,81 , ses çıkarmanın 0,86 , bağlılığın 0,84 ve ihmal etme ölçeğinin ise 0,88 olarak belirlenmiştir. Dolayısıyla çalışmada kullanılan tüm ölçeklerin Cronbach Alfa katsayılarının 0,70 'in üzerinde olması ölçeğin iç tutarlılığının sağlandığını ortaya koymaktadır.

Tablo 1: Değişkenlere Ait Cronbach Alfa Değerleri ve Değişkenler Arasındaki Korelasyon Katsay1ları

\begin{tabular}{lccccccc}
\hline & $\boldsymbol{\alpha}$ & $\mathbf{( 1 )}$ & $\mathbf{( 2 )}$ & $\mathbf{( 3 )}$ & $\mathbf{( 4 )}$ & $\mathbf{( 5 )}$ & $\mathbf{( 6 )}$ \\
\hline $\begin{array}{l}\text { (1) Örgütsel } \\
\text { Politika AlgıSı }\end{array}$ & 0,82 & 1 & & & & & \\
(2) İş Tatmini & 0,91 & $-0,451^{* *}$ & 1 & & & & \\
(3) Örgütten & 0,81 & $0,561^{* *}$ & $-0,536^{* *}$ & 1 & & & \\
Ayrilma & & & & & & & \\
(4) Ses Çıkarma & 0,86 & $-0,362^{* *}$ & $0,635^{* *}$ & $-0,454^{* *}$ & 1 & & \\
(5) Sadakat & 0,84 & $-0,403^{* *}$ & $0,486^{* *}$ & $-0,407^{* *}$ & $0,522^{* *}$ & 1 & \\
(6) İhmal Etme & 0,88 & $0,341^{* *}$ & $-0,441^{* *}$ & $0,436^{* *}$ & $-0,574^{* *}$ & $-0,451^{* *}$ & 1 \\
\hline
\end{tabular}


Ede edilen sonuçlara göre, örgütsel politika algısı ile iş tatmini $(r=-0,451, p<0,01)$, ses çıkarma $(r=-0,362, p<0,01)$ ve sadakat $(r=-0,403, p<0,01)$ arasında istatistiksel olarak anlamlı ve negatif yönlü ilişki bulunduğu belirlenirken; örgütten ayrılma $(\mathrm{r}=0,561, \mathrm{p}<0,01)$ ve ihmal etme $(\mathrm{r}=0,341, \mathrm{p}<0,01)$ davranışı arasında anlamlı ve pozitif yönlü ilişki bulunduğu belirlenmiştir. Buna göre iş yerinde politik davranışlar sergilendiğini düşünen çalışanların iş tatminleri düşmekte, örgütten ayrılmayı daha fazla düşünmekte veya işlerini ihmal edebilmektedirler. Buna karşılık örgütlerine duydukları sadakat azalmakta ve örgütteki yanlış uygulamaları düzletmek için herhangi bir çaba harcamak yerine sessiz kalmayı tercih etmektedirler. Benzer şekilde, iş tatmini ile sadakat $(r=0,486, p<0,01)$ ve ses çıkarma $(r=0,635, p<0.01)$ arasında pozitif, örgütten ayrılma $(r=-0,536, p<0,01)$ ve ihmal etme $(\mathrm{r}=-0,441, \mathrm{p}<0,01)$ davranışı arasında ise negatif doğrusal bir ilişki olduğu ortaya konulmuştur. Buna göre, iş tatmini yüksek çalışanların örgütlerine sadakati artmakta ve örgütteki yanlış uygulamaların düzelmesi için daha fazla tepki göstermekte, örgütten ayrılma ve işlerini ihmal gibi olumsuz davranışları daha az sergilemektedirler.

\subsection{Yapısal Eşitlik Modeline İlişkin Bulgular}

Çalışma kapsamında geliştirilen hipotezlerin test edilmesi amacıyla yapılan Yapısal Eşitlik Modeli (YEM) analizi sonucunda kurulan modele ilişkin elde edilen uyum iyiliği değerleri $(\chi 2 / \mathrm{sd}=1,73 ; \mathrm{p}<0,01 ; \mathrm{GFI}=0,85 ; \mathrm{CFI}=0,95 ; \mathrm{RMSEA}=0,05)$ modelin iyi uyum sağladığını ortaya koymaktadır.

Şekil 3: Yapısal Eşitlik Modeli

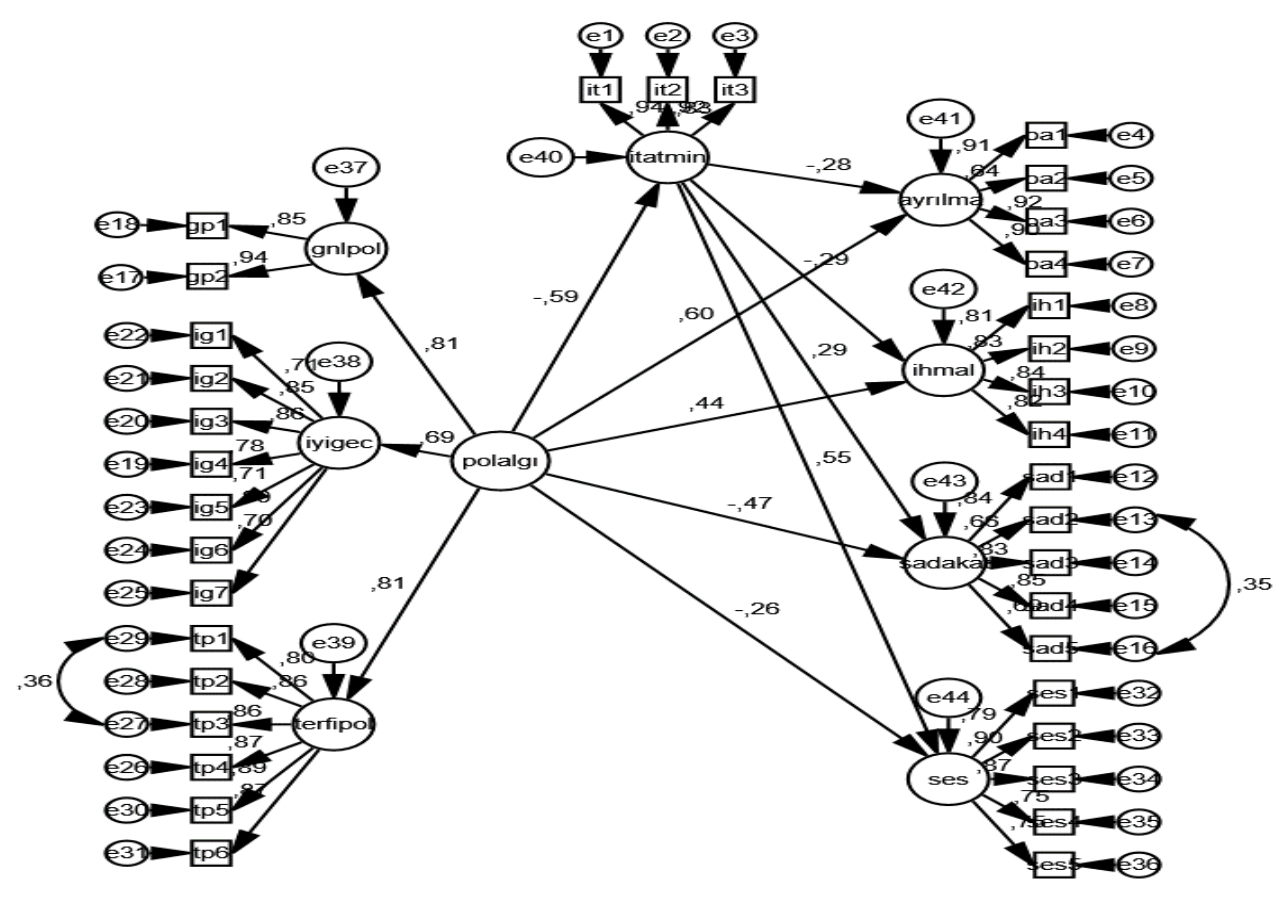


Yapılan analize ilişkin sonuçların yer aldığı Şekil 3'teki değerlere göre, örgütsel politika algısının, iş tatmini, ses çıkarma ve sadakat üzerinde negatif; örgütten ayrılma ve ihmal etme davranışı üzerinde ise pozitif yönlü etkisi bulunmaktadır. Dolayısıyla, çalışma kapsamında geliştirilen $\mathrm{H}_{1}, \mathrm{H}_{2}, \mathrm{H}_{3}, \mathrm{H}_{4}$ ve $\mathrm{H}_{5}$ hipotezleri desteklenmektedir. Ayrıca iş tatmininin sadakat ve ses çıkarma üzerinde pozitif yönlü etkisi olduğunu öne süren $\mathrm{H}_{7}$ ve $\mathrm{H}_{8}$ hipotezleri ile örgütten ayrılma ve ihmal etme üzerinde negatif yönlü etkisi olduğunu öne süren $\mathrm{H}_{6}$ ve $\mathrm{H}_{9}$ hipotezlerinin de desteklendiği görülmektedir. Yapılan yol analizi ile örgütsel politika algısı, iş tatmini, örgütten ayrılma, ses çıkarma, sadakat ve ihmal etme arasındaki doğrudan ilişkilerin yanı sıra Bootstrap yöntemi kullanılarak değişkenler arasındaki dolaylı etkiler de ortaya konulmuştur. Buna göre, gerçekleştirilen analiz sonucu ortaya çıkan değişkenler arasındaki dolaylı etkiler Tablo 2'de yer almaktadır.

Tablo 2: Değişkenler Arasındaki Doğrudan ve Dolaylı Etkiler

\begin{tabular}{lccc}
\hline Etki & Doğrudan Etki & Dolaylı Etki & Toplam Etki \\
\hline $\mathbf{P O L} \rightarrow$ IT & $-0,585^{* *}$ & & \\
\hline POL $\rightarrow$ ÖA & $0,596^{* *}$ & & $0,762^{* *}$ \\
\hline $\mathbf{P O L} \rightarrow$ IE & $0,438^{* *}$ & & $0,608^{* *}$ \\
\hline $\mathbf{P O L} \rightarrow$ SAD & $-0,470^{* *}$ & & $-0,643^{* *}$ \\
\hline $\mathbf{P O L} \rightarrow$ SES & $-0,260^{* *}$ & & $-0,585^{* *}$ \\
\hline $\mathbf{P O L} \rightarrow$ IT $\rightarrow$ ÖA & & $0,166^{* *}$ & \\
\hline $\mathbf{P O L} \rightarrow$ İT $\rightarrow$ İE & & $0,170^{* *}$ & \\
\hline $\mathbf{P O L} \rightarrow$ IT $\rightarrow$ SAD & & $-0,172^{* *}$ & \\
\hline $\mathbf{P O L} \rightarrow$ IT $\rightarrow$ SES & & $-0,325^{* *}$ & \\
\hline
\end{tabular}

*p<0,05, **p<0,01 POL: Örgütsel Politika, İT: İş Tatmini, ÖA: Örgütten Ayrılma, İE: İhmal Etme, SAD: Sadakat, SES: Ses Çıkarma

Elde edilen bulgulara göre örgütsel politika algısının örgütten ayrılmaya etkisinde iş tatmininin aracılık rolü olduğuna dair geliştirilen $\mathrm{H}_{10}$ hipotezi $\left(\beta=0,166^{* *}(0,043)\right.$, \%95GA $\mathrm{BCA}=[0,093-0,263])$; ihmal etme davranışına etkisinde iş tatmininin aracılık rolü olduğuna dair geliştirilen $\mathrm{H}_{11}$ hipotezi $(\beta=0,170 * *(0,075)$, \%95GA $\mathrm{BCA}=[0,050-0,298])$; sadakate etkisinde iş tatmininin aracılık rolü olduğuna dair geliştirilen $\mathrm{H}_{12}$ hipotezi $(\beta=0,172 * *(0,067), \% 95 \mathrm{GA} \mathrm{BCA}=[-0,282--0,058])$ ve ses çıkarma davranışına etkisinde iş tatmininin aracılık rolü olduğuna dair geliştirilen $\mathrm{H}_{13}$ hipotezinin $(\beta=0,325 * *(0,062), \% 95 \mathrm{GA} \mathrm{BCA}=[-0,446--0,229])$; desteklendiği görülmektedir.

\section{Sonuç}

Örgüt içindeki kazanımların dağılımını etkilemek için örgütün resmi kuralları tarafından tanınmayan araçları kullanarak bireyin kendi kişisel çıkarlarını maksimize etmesini ifade eden örgütsel politika, doğru şekilde yönetilemezse örgüt ve çalışanlar açısından tehlikeli sonuçlara yol açabilmektedir. Bu nedenle, örgütsel politika olgusunun örgütler açısından önemi son yıllarda akademisyenler tarafından sıkça vurgulanmakta ve örgütsel davranış ve insan kaynakları yönetimi alanında önemli bir konu olarak ön plana çıkmaktadır (Sun ve Xia, 2018). Bu 
bağlamda bu çalışma ile birçok olumsuz iş sonucuna yol açan ve örgüt dinamikleri içerisinde kaçınılmaz bir yapı olan örgütsel politika algısına çalışanların verdikleri tepkilerin (örgütten ayrılma, ses çıkarma, sadakat, ihmal etme) tespit edilmesi ve bu tepkilerin belirlenmesinde iş tatmininin rolünün ortaya konulması amaçlanmıştır. Bu doğrultuda gerçekleştirilen çalışma sonucu elde edilen bulgular, çalışanların örgütte politik davranışların olduğuna dair algıları arttıkça daha fazla tatminsizlik duygusu yaşadıklarını ortaya koymaktadır. Benzer şekilde, politik davranışların var olduğuna dair algıya çalışanların örgütten ayrılma, işlerini ihmal etme davranışlarını sergileyerek veya sessiz kalmayı tercih ederek tepki gösterdikleri ve politika algısının örgüte olan sadakat duygusunu olumsuz etkilediği yapılan çalışma sonucu ortaya konulmuştur. Daha önce örgütsel politika ile ilgili yapılmış olan çalışmaların (Cropanzano vd., 1997; Julius, Ojiabo ve Alagah, 2017; Witt vd., 2000) bulgular1 örgütsel politika alg1s1 ile iş tatmini, örgütten ayrılma, işini ihmal etme, sadakat ve ses çıkarma arasındaki ilişkilere yönelik ortaya konulan bu sonuçları destekler niteliktedir.

Çalışmada elde edilen diğer bir sonuç da çalışanların işleriyle ilgili tatmin duygusu yaşaması durumunda çalıştığı örgüte karşı sadakatinin artacağı ve örgüt içerisindeki yanlış uygulamalara daha fazla tepki göstereceği; buna karşılık örgütten ayrılma ve işlerini ihmal etme gibi davranışlarının ise azalacağıdır. Geçmişte yapılmış olan çalışmalar bu sonuçları desteklemektedir (Farrell, 1983; Hagedoorn vd., 1999; Rusbult vd., 1988; Withey ve Cooper, 1989). Çalışmada bu doğrudan ilişkilerin yanı sıra örgütsel politika algısının örgütten ayrılma, ses çıkarma, sadakat ve ihmal etme üzerine olan etkisinde iş tatmininin aracılık rolü de ele alınmıştır. Yapılan çalışma sonucunda, örgütsel politika algısı ile örgütten ayrılma, ses çıkarma, sadakat ve ihmal etme arasındaki ilişkide iş tatmininin aracılık etkisinin olduğu ortaya konulmuştur. Buna göre, örgüt içerisindeki politik davranışlar örgütlerde yaygın olarak görülmesi ve iş sonuçları üzerinde önemli etkileri nedeniyle daha fazla dikkat edilmesi ve ampirik olarak incelenmesi gereken bir konu olarak değerlendirilmektedir.

Politik davranışlar zamanla örgütsel süreçlere (örneğin karar verme, terfi ve ödüller) zarar vermekte, bireysel ve örgütsel düzeyde verimlilik ve performans1 olumsuz etkilemektedir. Ortaya çıkabilecek bu tür olumsuz sonuçları önleyebilmek için yöneticiler çalışanların örgütsel politika algılarını etkilemenin yolunu bulmalıdırlar. Bunun yollarından birisi çalışanların karar verme sürecine katılımlarının sağlanmasıdır. Çalışanlara karar alma sürecine katılma fırsatını vermek, kararların nasıl alındığına ilişkin anlayışlarını arttıracak, böylece bu konuda sahip olabilecekleri olumsuz düşüncelerin önüne geçilebilecektir. Çalışma ortamlarını anlayan veya kontrol edebilen çalışanlar da çok az kontrol veya anlayışa sahip çalışanlara göre politik davranışlara daha az tepki verecektir. Çalışanların örgütsel politika algısını etkileyebilecek diğer bir unsur çalışanlara örgüt içerisindeki davranışlarını düzenleyen kabul edilebilir ilkelerle ilgili geribildirimde bulunulmasidir. 
Çalışanlar örgüt içerisindeki temel kurallar konusunda yeterince bilgi sahibi olmadığında kendi kurallarını belirleyecek bu durumda da çoğu kişi kendi çıkarlarına hizmet edecek kurallar geliştirecektir. Genellikle politik eylemler olarak ifade edilen bu tür davranışlar ortaya çıktığında, bireylerin örgütsel politika algıları da artacaktır. Bunun önüne geçebilmek için çalışanların örgüt içerisindeki davranışlarını kontrol edebilecek yönetmelik ve düzenlemelerin açık ve anlaşılır bir şekilde oluşturulması ve bununla ilgili çalışanların yeterince bilgilendirilmesi gerekmektedir. Son olarak, yöneticiler, çalışanların örgütsel politika algılarını artıran bir unsur olan terfi kararlarını adil bir şekilde vermeli ve bu konuda tüm çalışanları inandırmalıdır. Terfi konusunda iş arkadaşlarına kıyasla sınırlı firsatlara sahip olduğunu düşünen çalışan bunu örgütsel politikanın bir sonucu olarak yorumlayacaktır. Dolayısıyla, yöneticiler terfi kararlarını ne kadar objektif ilkelere dayandırır ve tüm çalışanlara eşit terfi fırsatı verirse, çalışanlarının örgüt içerisinde politik davranışların var olduğuna dair algıları o kadar düşük olacaktır.

Örgütsel politika algısı, iş tatmini, çalışanların örgütten ayrılma, ses çıkarma, sadakat ve ihmal etme davranışları arasındaki ilişkilerin ortaya konulduğu bu çalışma, her çalışmada olduğu gibi bir takım kısıtlar içermektedir. Çalışmanın tek sektörde yapılmış olması araştırmanın önemli bir kısıtıdır. Bundan sonraki çalışmalarda farklı sektörlerdeki çalışanlarla araştırmalar gerçekleştirilmesi sektörler arasında karşılaştırmalı değerlendirmeler yapılması anlamında faydalı olabilecektir. Çalışanın diğer bir kısıtı kesitsel bir çalışma olmasıdır. Gelecekte yapılacak çalışmalarda söz konusu değişkenlerin belirli zaman aralığında tekrarlanan bir şekilde ölçülmesi farklı zaman dilimlerinde ortaya çıkabilecek farklılıkları da ortaya koyabilmek adına faydalı olacaktır. İçermiş olduğu tüm bu kısıtlara rağmen, bu çalışma ile örgüt içerisindeki politik davranışların çalışanların iş tatminleri üzerindeki etkisi ile bu tür davranışlara verdikleri tepkileri ortaya koyarak literatüre ve söz konusu ilişkilerin çalışma yaşamında değerlendirilerek yaşanabilecek olumsuzlukların önüne geçilmesini sağlayacak düzenlemelere 1şık tutarak da uygulamaya katkı sağlaması beklenmektedir.

\section{Kaynakça}

Arif, A. \& Chohan, A. (2012). How job satisfaction is influencing the organizational citizenship behavior (OCB): A study on employees. Interdisciplinary Journal of Contemporary Research in Business, 4(8), 74-88.

Aybar, S. \& Marşap, A. (2018). Örgütsel politika algısı ile örgütsel bağl1lık ilişkisinde örgütsel güvenin düzenleyici rolünün belirlenmesine yönelik İstanbul'daki üniversitelerde bir araştırma. Işsletme Araştırmaları Dergisi, 10(2), 758-782.

Aziri, B. (2011). Job satisfaction: A literature review. Management Research and Practice, 3(1), 77-90. 
Başar, U. \& Varoğlu, A. K. (2016). Örgütsel politika algısının ihmalkârlık üzerindeki etkisinde işten ayrılma niyetinin aracı rolü. Yönetim ve Ekonomi, 23(3), 751-765.

Bateman, T. S. \& Organ, D. W. (1983). Job satisfaction and the good soldier: the relationship between affect and employee citizenship. Academy of Management Journal, 26(4), 587-595.

Bridges, E. M. (1980). Job satisfaction and teacher absenteeism. Educational Administration Quarterly, 16(2), 41-56.

Cacciattolo, K. (2015). Organisational politics: The positive \& negative sides. European Scientific Journal, 11(1), 1857-1881.

Cammann, C., Fichman, M., Jenkins, G. D. \& Klesh, J. (1983). Michigan organizational assessment questionnaire. In S.E. Seashore, E. E. Lawler, P. H. Mirvis \& C. Cammann (Eds.), Assessing organizational change: A guide to methods, measures, and practices (pp. 71-138), New York: Wiley-Interscience

Cropanzano, R., Howes, J. C., Grandey, A.A. \& Toth, P. (1997). The relationship of organizational politics and support to work behaviors, attitudes, and stress. Journal of Organizational Behavior, 18(2), 159-180.

Cropanzano, R. S., Kacmar. K. M. \& Bozeman, D. P. (1995). The social setting of work organizations: Politics, justice and support. in R.S. Cropanzano \& K.M. Kacmar (Eds.), Organizational politics, justice, and support: Managing the social climate in the workplace (pp. 1-18). Westport, CT: Quorum Books.

Curtis, S. (2003). Lies, damned lies and organisational politics. Industrial and Commercial Training, 35(7), 293-297.

Drory, A. \& Romm, T. (1990). The definition of organizational politics: A review. Human Relations, 43(11), 1133-1154.

Farrell, D. (1983). Exit, voice, loyalty, and neglect as responses to job dissatisfaction: A multidimensional scaling study. Academy of Management Journal, 26(4), 596-607.

Ferris, G. R. \& Kacmar, K. M. (1992). Perceptions of Organizational Politics. Journal of Management, 18(1), 93-116.

Ferris, G. R., Perrewé, P. L., Daniels, S. R., Lawong, D. \& Holmes, J. J. (2017). Social influence and politics in organizational research: What we know and what we need to know. Journal of Leadership and Organizational Studies, 24(1), 5-19.

Ferris, G. R., Russ, G. S. \& Fandt, P. M. (1989). Politics in organizations. In R.A. Giacalone \& P. Rosenfeld (Eds), Impression management in the organization (pp.143-170). Hillsdale, NJ: Erlbaum. 
Goo, W., Choi, Y. \& Choi, W. (2019). Coworkers' organizational citizenship behaviors and employees' work attitudes: The moderating roles of perceptions of organizational politics and task interdependence. Journal of Management \& Organization, 1-25.

Gull, S. \& Zaidi, A. A. (2012). Impact of Organizational Politics on Employees' Job Satisfaction in the Health Sector of Lahore Pakistan. Interdisciplinary Journal of Contemporary Research In Business, 4(2), 156-170.

Gürbüz, S. \& Şahin, F. (2017). Sosyal bilimlerde araştırma yöntemleri felsefe, yöntem, analiz (4. Baskı). Ankara: Seçkin Yayıncılık.

Hackman, J. R., \& Oldham, G. R. (1974). The job diagnostic survey: an instrument for the diagnosis of jobs and the evaluation of job redesign projects. Report No. 4, Yale University, Department of Administration Science, New Haven, CT., (1).

Hagedoorn, M., Van Yperen, N. W., Van De Vliert, E. \& Buunk, B. P. (1999). Employees' reactions to problematic events: a circumplex structure of five categories of responses, and the role of job satisfaction. Journal of Organizational Behavior, 321(20), 309-321.

Hsiung, H. H. \& Yang, K. P. (2012). Employee behavioral options in problematic working conditions: Response pattern analysis. International Journal of Human Resource Management, 23(9), 1888-1907.

Huang, I. C., Chuang, C. H. J. \& Lin, H. C. (2003). The role of burnout in the relationship between perceptions of organizational politics and turnover intentions. Public Personnel Management, 32(4), 519-531.

Iaffaldano, M. \& Muchinsky, P. (1985). Job satisfaction and job performance. American Psychological Association Inc., 97(2), 251-273.

Igelans, J. \& Roussel, P. (1999). A study of the relationships between compensation package, work motivation and job satisfaction. Journal of Organizational Behavior, 20(1), 1003-1025.

Iqbal, Q. (2016). Organizational politics, transformational leadership and neglect in banking sector. International Journal of Management, Accounting and Economics, 3(10), 609-622.

Judge, T. A. \& Klinger, R. (2008). Job satisfaction: Subjective well-being at work. M. Eid ve R. J. Larsen (Ed.), The Science of Subjective Well-Being içinde (pp. 393-413). New York, NY: The Guilford Press.

Judge, T. A., Parker, S., Colbert, A. E., Heller D. \& Ilies, R. (2001). Job satisfaction: A cross-cultural review. In N. Anderson, D. S. Ones, H. K. Sinangil, and C. Viswesvaran (Eds.), Handbook of Industrial, Work and Organizational Psychology (pp.25-52). London: Sage. 
Judge, T. A., Thoresen, C. J., Bono, J. E. \& Patton, G. K. (2001). The job satisfaction-job performance relationship: A qualitative and quantitative review. Psychological Bulletin, 127(3), 376-407.

Julius, N. T., Ojiabo, U. \& Alagah, D. (2017). Organizational politics and employee's job satisfaction in the health sector of rivers state. IJARR International Journal of Advanced Academic Research, 3(7), 88-106.

Kacmar, K. M. \& Carlson, D. S. (1997). Further validation of the perceptions of politics scale (POPS): A multiple sample investigation. Journal of Management, 23(5), 627-658.

Kacmar, K. M. \& Ferris, G. R. (1991). Perceptions of organizational politics scale (POPS): Development and construct validation. Educational and Psychological Measurement, 51(1), 193-205.

Kacmar, K. M. \& Ferris, G. R. (1993). Politics at work: Sharpening the focus of political behavior in organizations. Business Horizons, 36(4), 70-74.

Kalleberg, A. L. (1977). Work values and job rewards: A theory of job satisfaction. American Sociological Association, 42(1), 124-143.

Kidron, A. \& Vinarski Peretz, H. (2018). Organizational political climate and employee engagement in political behavior in public sector organizations: A mixed methods study. International Journal of Organizational Analysis, 26(4), $773-795$.

Landells, E. \& Albrecht, S. L. (2013). Organizational political climate: Shared perceptions about the building and use of power bases. Human Resource Management Review, 23(4), 357-365.

Leck, J. D. \& Saunders, D. M. (1992). Hirschman's loyalty: Attitude or behavior?, Employee Responsibilities and Rights Journal, 5(3), 219-230.

Locke, E. A. (1969). What is job satisfaction? Organizational Behavior \& Human Performance, 4(4), 309-336.

Markovits, Y., Davis, A. J., Fay, D. \& van Dick, R. (2010). The link between job satisfaction and organizational commitment: Differences between public and private sector employees. International Public Management Journal, 13(2), $177-196$.

Matrunola, P. (1996). Is there a relationship hetween job satisfaction and ahsenteeism?. Journal of Advanced Nursing, 23, 827-834.

McLain, D. L. (1995). Responses to health and safety risk in the work environment. Academy of Management Journal. 38(6), 1726-1743.

Netemeyer, R. G., Burton, S. \& Johnson, M. W. (1995). A nested comparison of four models of the consequences of role perception variables. Organizational Behavior and Human Decision Processes, 61(1), 77-93. 
Öztürk, İ. \& Ay, Ü. (2018). İşgörenin görev bağımlılı̆̆ı, politik davranışları, rol çatışması ve belirsizliğinin tükenmişlik üzerindeki etkisi: Sağlık kurumlarında bir inceleme. B. Polat, M. Güler ve H. Derin (Ed.), Sosyal Bilimler Üzerine Araştırmalar (68-101) içinde, İksad Publishing House.

Panayides, P. (2013). Coefficient alpha: Interpret with caution. Europe's Journal of Psychology, 9(4), 687-696.

Rusbult, C. E., Farrell, D., Rogers, G. \& Mainous, A. G. (1988). Impact of exchange variables on exit, voice, loyalty, and neglect: An integrative model of responses to declining job status satisfaction. Academy of Management Journal, 31(3), 599-627.

Rusbult, C. E. \& Zembrodt, I. M. (1983). Responses to dissatisfaction in romantic involvements: A multidimensional scaling analysis. Journal of Experimental Social Psychology, 19(3), 274-293.

Rusbult, Caryl E., Zembrodt, I. M. \& Gunn, L. K. (1982). Exit, voice, loyalty, and neglect: Responses to dissatisfaction in romantic involvements. Journal of Personality and Social Psychology, 43(6), 1230-1242.

Schappe, S. P. (1998). The influence of job satisfaction, organizational commitment, and fairness perceptions on organizational citizenship behavior. Journal of Psychology: Interdisciplinary and Applied, 132(3), 277-290.

Scott, A., Gravelle, H., Simoens, S., Bojke, C. \& Sibbald, B. (2006). Job satisfaction and quitting intentions: A structural model of British general practitioners. British Journal of Industrial Relations, 44(3), 519-540.

Scott, K. D. \& Taylor, G. S. (1985). An examination of conflicting findings on the relationship between job satisfaction and absenteeism: A meta-analysis. Academy of Management Journal, 28(3), 599-612.

Shin, J. (2013). Employee Voice Behavior During Organizational Change. University of Maryland.

Siegall, M. \& McDonald, T. (1995). Focus of attention and employee reactions to job change. Journal of Applied Social Psychology, 25(13), 1121-1141.

Sun, Y. \& Xia, H. (2018). Research on perceptions of organizational politics and 1ts influence on employee silence. Open Journal of Business and Management, 6(2), 250-264.

Vigoda-Gadot, E. \& Talmud, I. (2010). Organizational Politics and Job Outcomes : Journal of Applied Social Psychology, 40(11), 2829-2861.

Vigoda, E. (2000). Organizational politics, job attitudes, and work outcomes: Exploration and implications for the public sector. Journal of Vocational Behavior, 57(3), 326-347. 
Vigoda, E. (2001). Reactions to organizational politics: A cross-cultural examination in Israel and Britain. Human Relations, 54(11), 1483-1518.

Williams, L. J. \& Hazer, J. T. (1986). Antecedents and consequences of satisfaction and commitment in turnover models: A reanalysis using latent variable structural equation methods. Journal of Applied Psychology, 71(2), 219-231.

Withey, M. J. \& Cooper, W. H. (1989). Predicting exit, voice, loyalty, and neglect. Administrative Science Quarterly, 34(4), 521-539.

Witt, L. A., Andrews, M. C. \& Kacmar, K. M. (2000). The role of participation in decision-making in the organizational politics-job satisfaction relationship. Human Relations, 53(3), 341-358. 